\title{
Penggunaan Gadget dan Perubahan Sosial Budaya pada Usia Produktif
}

\section{The Use of Gadget and Sociocultural Change in Productive Age}

\author{
Maman Wijaya' ${ }^{1}$, Vini Kartika Rachmawati ${ }^{2}$, Arief Rachman Hakim³
}

1,2,3 Kementerian Koordinator Bidang Pembangunan Manusia dan Kebudayaan

\section{Penulis Korespondensi}

Arief Rachman Hakim ariefraxman@gmail.com +62 85233270426

\begin{abstract}
Abstrak
Penggunaan gadget saat ini sangat masif pada setiap rentang usia di setiap wilayah. Tidak diketahui dengan pasti kebiasaan apa saja yang hilang, budaya apa saja yang berubah, dan pada usia berapa saja yang mengalami perubahan itu. Penelitian ini berupa analisis deskriptif, bertujuan untuk menelaah penggunaan gadget dan hubungannya terhadap perubahan sosial budaya responden yang dikelompokkan berdasarkan usia. Perubahan sosial budaya didasarkan pada teori Weberian. Metode yang digunakan adalah survei dengan instrumen angket yang disusun dalam Google Form dan disebar melalui aplikasi WhatsApp selama $2 \times 24$ jam dan terkumpul sebanyak 197 responden. Data diolah dengan IBB SPSS Statistics Data Editor. Pengolahan data mencakup frekuensi, distribusi, dan kecenderungan data, serta untuk beberapa variabel dihitung korelasinya. Hasilnya menunjukkan bahwa penggunaan gadget mengubah kebiasaan orang, baik usia muda, maupun usia lanjut. Terdapat sejumlah kebiasaan lama yang hilang disertai dengan munculnya sejumlah kebiasaan baru. Kebiasaan lama yang hilang dan kebiasaan baru yang muncul tidak berhubungan secara signifikan dengan usia, tetapi berhubungan signifikan dengan cara memfungsikan gadget sebagai alat kerja dan alat usaha dengan koefisien korelasi masing-masing sebesar 0,77 dan 0,42. Objek pemajuan kebudayaan seperti tradisi lisan, manuskrip dan permainan tradisional relatif tidak dikenal, terutama pada rentang usia 20-40 tahun. Dengan demikian, perubahan sosial budaya yang terjadi pada diri responden sangat erat hubungannya dengan penggunaan gadget.
\end{abstract}

\section{Kata Kunci}

penggunaan gadget; perubahan sosial budaya; usia produktif; objek pemajuan kebudayaan

\section{Abstract}

The use of gadgets is very massive in every age range in every region. It is not known with certainty what habits have been forgotten, what cultures have changed, and at what ages experienced these changes. This descriptive analysis study aims to examine the use of gadgets and their relationship to changes in the sociocultural of respondents who are grouped by age. Sociocultural change is based on Weberian Theory. The method used a survey with questionnaire instrument arranged in google form which is distributed through the WhatsApp application for $2 \times 24$ hours and received 197 respondents. The data is processed by IBB SPSS Statistics Data Editor. Data processing includes the frequency, distribution, and trend of the data, as well as for several variables, the correlation is calculated at the 95\% confidence level. The results show that the use of gadgets changes people's habits, both young and old. Several old habits are forgotten with the emergence of several new habits. Old habits that are forgotten and new habits that emergence are not significantly related to age but have a significant relationship with how to function gadgets as work tools and business tools with correlation coefficients about 0.77 and 0.42 . Objects of cultural development such as oral traditions, manuscripts, and traditional games are relatively unfamiliar, especially in the age range of 20-40 years. Thus, the changes in the respondent's sociocultural are related to the use of gadgets.

\section{Keywords}

the use of gadget; sociocultural change; productive age; cultural advancement object 


\section{Pendahuluan}

Gadget, yang dalam penelitian ini didefinisikan sebagai handphone, tablet, iPad, atau laptop, saat ini telah dimiliki oleh berbagai kalangan, baik anak-anak (Hermawan, 2021, hal. 3) maupun orang tua, mulai dari kota-kota besar sampai ke pelosok desa (Zulkarnain dkk., 2016, hal. 1). Penggunaannya meningkat tajam, terutama dalam satu tahun terakhir dikarenakan pandemi Covid-19 yang membatasi ruang gerak orang-orang secara fisik (Mungkasa, 2020, hal. 146).

Penelitian ini merupakan analisis deskriptif tentang penggunaan gadget dan perubahan sosial budaya pada usia produktif. Tujuannya adalah untuk menelaah hubungan antara penggunaan gadget dengan perubahan sosial budaya para responden dalam rentang usia produktif.

Gadget pertama kali dikenal tahun 1990-an dengan fungsi yang terbatas. Saat ini penggunaannya sangat luas. Setidaknya belakangan ini fungsi gadget selain untuk keperluan individu, juga untuk komunikasi antar individu, individu dengan organisasi, atau organisasi dengan organisasi (Zulkarnain dkk., 2016).

Pada usia produktif, yaitu rentang usia antara 15-64 tahun (Muhaemin, 2021, hal. 201), dalam masa pandemi seperti sekarang ini, gadget digunakan terutama untuk menunjang pekerjaan (Mungkasa, 2020), baik yang bekerja dari rumah (WFH/ Work from Home) maupun yang bekerja dari kantor (WFO/Work from Office). Banyak hasil penelitian yang menggambarkan bahwa penggunaan gadget berpengaruh pada penggunanya, seperti di antaranya yang dikemukakan oleh Fitriana dkk. (2020, hal. 192), Haratanti dkk. (2019, hal. 366) dan Adrian (2019), yang menyatakan adanya perubahan perilaku dan pola kebiasaan hidup. Pengaruhnya ada yang bersifat positif, ada yang negatif, serta ada yang bersifat fisik maupun psikis (Rahmawati dkk., 2020).

Perubahan perilaku dan pola kebiasaan tersebut selanjutnya membentuk warna baru dalam kehidupan akibat akulturasi dan asimilasi. Pola itulah yang kemudian menjadi dasar dari proses perubahan sosial budaya (Yoga, 2018, hal. 35). Hal yang sama dikemukakan juga oleh Rais dkk. (2018, hal. 65), yang menyatakan bahwa perubahan kebiasaan serta perilaku yang terus menerus akan menyebabkan adanya perubahan sosial budaya.

Betulkah setelah sekian lama menggunakan gadget yang intensif itu ada kebiasaan lama yang hilang? Apakah ada juga kebiasaan baru yang muncul? Bagaimana dengan nasib Sepuluh Objek Pemajuan Kebudayaan (10 OPK), seperti tradisi lisan, manuskrip, atau permainan tradisional, apakah kaum milenial yang saat ini berada pada usia produktif memahaminya dengan baik? Apakah betul pula ada perubahan perilaku sosial dalam penggunaan gadget?

Jawaban atas pertanyaan-pertanyaan tersebut sangat menarik untuk diteliti. Data yang dihasilkan akan berguna bagi para pengambil kebijakan untuk lebih mengoptimalkan fungsi gadget dalam meningkatkan produktivitas kerja sekaligus dalam upaya pemajuan kebudayaan.

Sebelum pandemi, Munawar dan Amri (2018) meneliti pengaruh gadget terhadap perkembangan perilaku anak usia dini di Kabupaten Aceh Besar. Temuannya menunjukkan bahwa penggunaan gadget pada anak usia dini memiliki pengaruh yang negatif bagi perkembangan perilaku, yaitu berupa sulitnya mengontrol emosi dan menjadi lebih agresif.

Hal itu sejalan dengan hasil penelitian yang dilakukan oleh Syifa dkk. (2019) yang meneliti sepuluh anak SD Kelas V yang menggunakan gadget selama 2 jam dalam sehari. Hasilnya, penggunaan gadget memiliki dampak negatif terhadap anak. Pertumbuhan emosinya menjadi labil, yaitu mudah marah dan membangkang, serta perkembangan moralnya terganggu, yaitu menjadi kurang disiplin dan malas. Sedangkan menurut hasil penelitian Dalillah (2019), penggunaan gadget pada siswa SMA menyatakan ada pengaruh tetapi pengaruhnya tidak signifikan terhadap perubahan perilaku sosial mereka.

Setelah merebaknya pandemi Covid-19, Rahmawati dkk. (2020) meneliti hal serupa. Mereka mengkaji hubungan antara penggunaan gadget terhadap perkembangan sosial emosional anak usia 5-6 tahun yang berstatus anak TK di Ponorogo. Temuannya adalah bahwa perkembangan sosial emosional anak erat kaitannya dengan penggunaan gadget. Penggunaan gadget pada anak-anak dapat mengubah pola asuh anak (Farida dkk., 2021, hal. 1707).

Sementara itu dari hasil penelitian yang dilakukan oleh Yanzi (2018, hal. 7) ditemukan bahwa tradisi lisan mulai memudar. Begitu juga halnya dengan manuskrip, pemahaman dan pemanfaatannya masih rendah (Hendrawati, 2018, hal. 24).

Selanjutnya, pada penelitian ini akan ditelaah dan dianalisis secara deskriptif mengenai penggunaan gadget dan perubahan sosial budaya pada usia produktif. Teori perubahan sosial budaya yang digunakan adalah Teori Perubahan Sosial yang dikemukakan oleh Max Weber dan Teori Interaksionisme Simbolik dari Herbert Blumer, yang sering disebut sebagai Teori Weberian. Teori tersebut digunakan sebab Max Weber mendasarkan perubahan perilaku sosial budaya itu akibat dari perilaku dan tindakan manusia yang ada di masyarakat (Syawaludin, 2017, hal. 115). Sedangkan Teori Interaksionisme Simbolik Herbert Blumer yang didasarkan pada Teori Max Weber mendefinisikan interaksi sosial yang menawarkan pendekatan penelitian ilmu sosial untuk menganalisis budaya atau sejarah secara fenomenologi (Syawaludin, 2017). Oleh karena itu kemudian kombinasinya disebut sebagai Teori Weberian, atau Vestehen Weberian.

Perubahan sosial budaya menurut teori ini sebagai akibat dari tindakan individu dan interaksi sosial di antaranya adalah yang ditandai dengan adanya kebiasaan lama yang hilang, kebiasaan baru yang muncul, termasuk perubahan pemahaman terhadap suatu objek. Pemahaman terhadap objek dalam penelitian ini diarahkan pada Objek Pemajuan 
Kebudayaan seperti tradisi lisan, manuskrip, dan permainan tradisional.

Jadi, fokus pembahasan dan analisis pada penelitian ini adalah mengenai kecenderungan perilaku dalam penggunaan gadget serta perubahan sosial budaya yang meliputi kebiasaan lama yang hilang dan kebiasaan baru yang muncul, pemahaman terhadap objek pemajuan kebudayaan serta hubungan satu sama lain di antara variabel-variabel tersebut.

\section{Metode}

Penelitian ini menyangkut manusia berikut tindakantindakannya serta interaksi sosial satu sama lain. Teori yang digunakan adalah Teori Interaksionisme Simbolik Herbert Blumer yang didasarkan pada Teori Perubahan Sosial Max Weber, yang dikenal dengan sebutan Vestehen Weberian. Menurut Weberian, perubahan sosial budaya dimulai dari perubahan kebiasaan (Syawaludin, 2017).

Dengan demikian, variabel yang diteliti meliputi kebiasaan dalam penggunaan gadget, kebiasaan yang hilang atau muncul sebagai bagian dari perubahan sosial budaya, dan usia responden, serta perubahan pemahaman terhadap suatu objek, yaitu Objek Pemajuan Kebudayaan (OPK).

Ada sepuluh OPK ada sepuluh macam, namun yang dikaji dalam penelitian ini hanyalah tiga macam, yaitu manuskrip, permainan tradisional, dan tradisi lisan, yang betul-betul terkait dan tersedia dalam fitur gadget. Contohnya permainan tradisional saat ini sudah tersedia aplikasinya di dalam gadget. Sebaliknya, Tradisi lisan, yang semula kebiasaan dengan lisan berubah menjadi kebiasaan mengetik dalam gadget. Sementara OPK yang lainnya seperti bahasa, ritus, atau seni relatif tidak terkait secara khusus dengan gadget.

Data yang dikumpulkan meliputi data pribadi (7 pertanyaan), jenis dan cara memfungsikan gadget (8 pertanyaan), perubahan yang dirasakan responden setelah menggunakan gadget ( 7 pertanyaan), dan pemahaman terhadap OPK (7 pertanyaan). Bentuk pertanyaan ada yang terbuka (diminta menuliskan), ada yang tertutup (berupa pilihan, salah satu). Contoh pertanyaan terbuka: nama, nomor Hp, sebutkan salah satu contoh Permainan Tradisional dalam Gadget. Contoh pertanyaan tertutup: Apakah Anda tahu arti dari Tradisi Lisan? Ya, Tidak.

Metode pengumpulan data dalam penelitian ini adalah survei dengan teknik angket berupa rangkaian pertanyaan yang disusun dalam Google Form dan disebarkan melalui aplikasi perpesanan WhatsApp. Selain alamat Google Form, dalam pesan WhatsApp tersebut juga disertakan permintaan untuk mengisi survei secara sukarela dan juga himbauan untuk mengirimkannya pada pihak lain.

Survei dilakukan selama $2 \times 24$ jam dari sejak pesan WhatsApp disebar sampai pada akses Google Form itu ditutup. Pada rentang waktu tersebut terkumpul sebanyak 197 responden. Pembatasan waktu dimaksudkan agar responden mengisi survei secara spontan, tidak memiliki banyak waktu untuk mencari jawaban dari sumber-sumber lain. Kemudian untuk validasi responden, dalam survei diminta mengisi nomor WhatsApp dan alamat email, yang kemudian alamat tersebut juga digunakan untuk membalas dan menyampaikan ucapan terima kasih atas partisipasi mereka pada survei.

Data yang terkumpul itu selanjutnya diolah dengan menggunakan IBM SPSS Statistics Data Editor. Pengolahan data yang dilakukan di antaranya adalah pengelompokan data berdasarkan variabel, menghitung frekuensi, dan beberapa korelasi antar variabel. Data hasil pengolahan ditampilkan dalam bentuk tabel dan grafik.

\section{Hasil dan Pembahasan}

Pada bagian ini diuraikan profil responden, hasil pengolahan data, serta analisis dan pembahasan.

\subsection{Profil Responden}

Responden yang terdata dari survei terdapat 197, terdiri dari laki-laki $56 \%$ dan perempuan 44\%. Aplikasi email yang digunakan: Gmail 80\%, Yahoo 12\%, dan lainnya 8\%. Gadget yang digunakan: handphone $87 \%$, laptop $8 \%$, tablet/desktop 5\%. Berdasarkan pekerjaan: PNS 72\%, Pegawai Swasta 12\%, Pelajar/Mahasiswa 5\%, Pemilik Usaha 3\%, BUMN 2\%, Lainnya $4 \%$. Karena responden yang terjaring itu dominan PNS, maka responden pengguna gadget dan yang berusia produktif itu dominan PNS juga. Konsekuensinya pada hasil penelitian ini adalah sulit membedakan penggunaan gadget pada usia produktif dari sisi jenis pekerjaan.

Kelompok responden berdasarkan usia: di bawah 20 tahun 0,6\%, antara 20-20 tahun 42,6\%, antara 30-40 tahun 13,7\%, antara 40-50 tahun 20.8\%, antara 50-60 tahun 22,3\%. Sedangkan media sosial utama yang digunakan: Instagram 42\%, WhatsApp 38\%, Twitter 12\%, dan Facebook $8 \%$. Aktivitas utama lain selain pekerjaan utama lihat Gambar 1. Profil lebih lengkap diperlihatkan dalam Tabel 1.

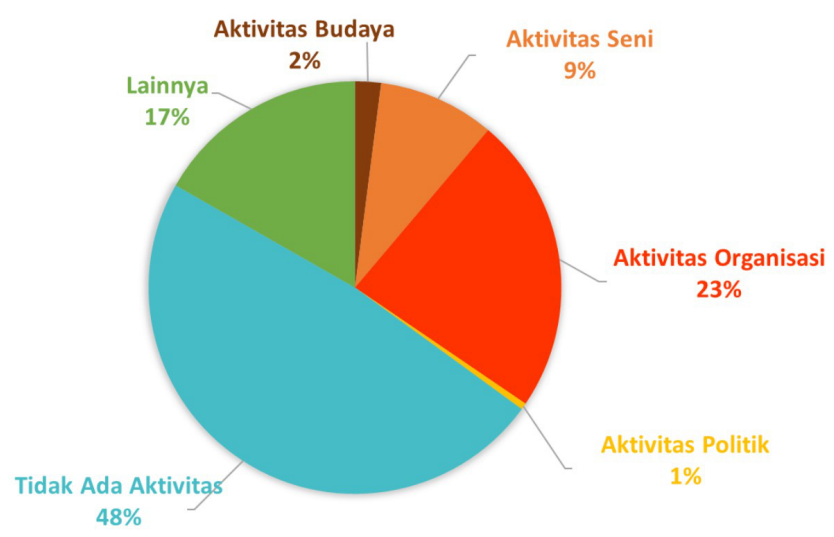

Gambar 1. Aktivitas lain selain pekerjaan utama yang dimiliki oleh responden 


\subsection{Hasil Pengolahan Data}

Dari hasil pengolahan data diperoleh informasi sebagai berikut, Penggunaan gadget jenis handphone (86,8\%), laptop $(8,1 \%)$, tablet/desktop (4,6\%), dan smartwatch $(0,5 \%)$ tidak memiliki korelasi dengan usia pengguna (koefisien korelasi $-0,28$ ), begitu juga dengan jenis kelamin (koefisien korelasi $0,206)$ tidak memiliki hubungan yang signifikan.

Keragaman cara menggunakan gadget digambarkan dengan memfungsikan gadget sebagai (1) alat penyimpan data dan alat komunikasi; (2) alat kerja dan usaha; (3) sumber informasi yang cepat dan terkini; (4) sumber informasi yang lengkap.

Sebanyak $73,1 \%$ responden menyatakan bahwa mereka menyimpan dan mengkomunikasikan dokumen di dalam gadget lebih dari $25 \%$ dari total dokumen yang diperlukan. Sisanya $(26,9 \%$ responden $)$ menyimpan dan mengkomunikasikan dokumen dalam gadget kurang dari $25 \%$. Hubungan antara usia pengguna dengan cara menyimpan dan mengomunikasikan dokumen dalam gadget memiliki hubungan yang signifikan dengan koefisien korelasi sebesar $-0,181$. Artinya, jumlah dokumen yang disimpan dan dikomunikasikan dalam gadget itu berbeda bila usia respondennya berbeda. Tanda negatif menunjukkan, semakin tinggi usia, semakin rendah jumlah dokumen yang disimpan dan dikomunikasikan dalam gadget.

Responden yang memfungsikan gadget sebagai alat kerja dan usaha sebanyak $52,8 \%$ dan sisanya $(47,2 \%)$ hanya memfungsikan salah satu atau tidak kedua-duanya (bukan alat kerja dan bukan alat usaha). Antara usia dan cara memfungsikan gadget sebagai alat kerja dan usaha memiliki hubungan yang signifikan dengan koefisien korelasi sebesar $-0,172$. Angka negatif menunjukkan bahwa kedua variabel mengalami perubahan ke arah berlawanan, artinya semakin tinggi penggunaan gadget sebagai alat kerja dan usaha maka usia semakin rendah.

Tabel 1. Profil Responden

\begin{tabular}{|c|c|c|c|c|c|c|c|c|}
\hline \multicolumn{9}{|c|}{ Jenis Kelamin * Usia * Pekerjaan Crosstabulation } \\
\hline \multicolumn{3}{|c|}{ Pekerjaan } & \multicolumn{5}{|c|}{ Usia } & \multirow[t]{2}{*}{ Total } \\
\hline & & & $U<20$ & $20=<U<30$ & $30=<U<40$ & $40=<U<50$ & $50=<U<60$ & \\
\hline \multirow[t]{3}{*}{ PNS } & Jenis Kelamin & Laki-laki & & 24 & 12 & 24 & 22 & 82 \\
\hline & & Perempuan & & 25 & 9 & 13 & 13 & 60 \\
\hline & Total & & & 49 & 21 & 37 & 35 & 142 \\
\hline \multirow[t]{3}{*}{ BUMN } & Jenis Kelamin & Laki-laki & & 1 & & & & 1 \\
\hline & & Perempuan & & 3 & & & & 3 \\
\hline & Total & & & 4 & & & & 4 \\
\hline \multirow[t]{3}{*}{ Pegawai Swasta } & Jenis Kelamin & Laki-laki & & 8 & 4 & 0 & 1 & 13 \\
\hline & & Perempuan & & 5 & 1 & 1 & 3 & 10 \\
\hline & Total & & & 13 & 5 & 1 & 4 & 23 \\
\hline \multirow[t]{3}{*}{ Wirausaha } & Jenis Kelamin & Laki-laki & & 2 & & & 1 & 3 \\
\hline & & Perempuan & & 2 & & & 0 & 2 \\
\hline & Total & & & 4 & & & 1 & 5 \\
\hline \multirow[t]{2}{*}{ Pemilik Usaha } & Jenis Kelamin & Laki-laki & & 1 & 1 & 1 & 2 & 5 \\
\hline & Total & & & 1 & 1 & 1 & 2 & 5 \\
\hline \multirow[t]{3}{*}{ Pelajar/ Mahasiswa } & Jenis Kelamin & Laki-laki & & 2 & & & & 2 \\
\hline & & Perempuan & & 8 & & & & 8 \\
\hline & Total & & & 10 & & & & 10 \\
\hline \multirow[t]{3}{*}{ Lainnya } & Jenis Kelamin & Laki-laki & 0 & 1 & & 1 & 2 & 4 \\
\hline & & Perempuan & 1 & 2 & & 1 & 0 & 4 \\
\hline & Total & & 1 & 3 & & 2 & 2 & 8 \\
\hline \multirow[t]{3}{*}{ Total } & Jenis Kelamin & Laki-laki & 0 & 39 & 17 & 26 & 28 & 110 \\
\hline & & Perempuan & 1 & 45 & 10 & 15 & 16 & 87 \\
\hline & Total & & 1 & 84 & 27 & 41 & 44 & 197 \\
\hline
\end{tabular}


Responden yang menyatakan bahwa sarana informasi yang cepat dan terkini diperoleh dari media sosial yang diakses melalui gadget sebanyak $77,7 \%$ responden, sedangkan sisanya (22,3\% responden) menyatakan website adalah sarana informasi yang lengkap dan terkini. Jenis aplikasi yang diakses dari gadget memiliki hubungan yang signifikan dengan usia responden (koefisien korelasi sebesar 0,153). Hal itu berarti bahwa usia responden yang berbeda memiliki pilihan aplikasi yang berbeda sebagai sarana informasi yang cepat dan terkini.

Dalam hal mencari informasi yang lengkap, responden yang menggunakan media sosial sebanyak $38,1 \%$, website $36,0 \%$, jurnal elektronik 18,3, guru/profesional 3\%, koran/majalah cetak $1,5 \%$, TV 2,5\%, dan lainnya sebesar $0,5 \%$. Antara pilihan sumber informasi lengkap dengan usia responden hubungannya tidak signifikan (koefisien korelasi 0,09).

Ketika responden ditanya, adakah kebiasaan lama yang hilang setelah terbiasa menggunakan gadget, sebanyak 78,7\% responden menjawab "Ya”, dan 21,3\% menjawab "Tidak". Saat dibedakan dengan kelompok usia, perbedaannya tidak signifikan (koefisien korelasi sebesar -0,133). Artinya hilangnya kebiasaan lama responden tidak bergantung pada usia.

Dalam hal kebiasaan lama yang hilang itu responden menyebutkan di antaranya menulis dan berkirim surat lewat pos, membaca buku cetak, atau membeli koran, dan kebiasaan kumpul-kumpul bersama teman sejawat. Hilangnya kebiasaan itu diartikan sebagai berkurangnya frekuensi sehingga menjadi tidak biasa lagi tetapi masih ada yang dilakukan.

Kemudian, saat responden ditanya, adakah kebiasaan baru yang muncul setelah sering menggunakan gadget, jawabannya sebanyak 91,9\% responden menjawab "Ya" dan 8,1\% menjawab "Tidak". Jawaban ya atau tidak dari responden tersebut hubungannya tidak signifikan dengan kategori usia (koefisien korelasinya -0,114). Hal itu menunjukkan bahwa munculnya kebiasaan baru tidak bergantung pada usia. Lebih lengkap data koefisien korelasi antar variabel dapat dilihat pada Tabel 1.

Berdasarkan perhitungan statistik, antara kebiasaan lama yang hilang dengan kebiasaan baru yang muncul memiliki hubungan yang signifikan, koefisien korelasinya sebesar 0,571. Hal itu menunjukkan bahwa perubahan kebiasaan lama sering dengan munculnya kebiasaan baru. Hal ini sesuai dengan hasil penelitian Fitriana dkk. (2020) yang mengkaji penggunaan gadget selama 5-7 jam sehari pada kalangan remaja dan pengaruhnya pada perilaku dalam keluarga. Mereka menyatakan bahwa kebiasaan-kebiasaan di rumah serta perilaku anggota keluarga antar yang satu dengan yang lainnya berubah dari sebelumnya (Fitriana dkk., 2020).

Dari grafik yang dilukiskan pada Gambar 2 diperoleh informasi bahwa responden yang merasa pada dirinya ada kebiasaan yang hilang, seluruhnya menyebutkan pada saat yang sama adan kebiasaan baru yang muncul. Beruntung tidak terjadi sebaliknya, yaitu kebiasaan lama hilang sementara kebiasaan baru tidak muncul (lihat bagian kanan atas pada

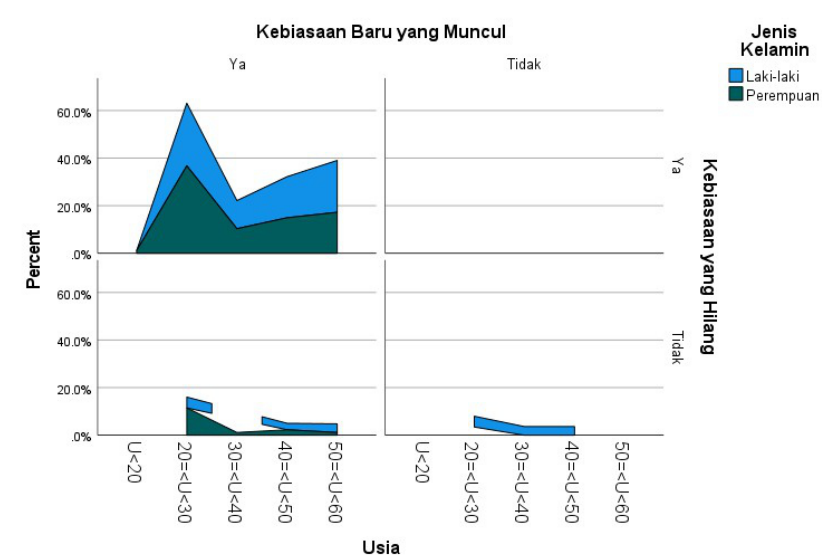

Gambar 2. Grafik kebiasaan yang hilang dan kebiasaan baru yang muncul pada responden laki-laki dan perempuan

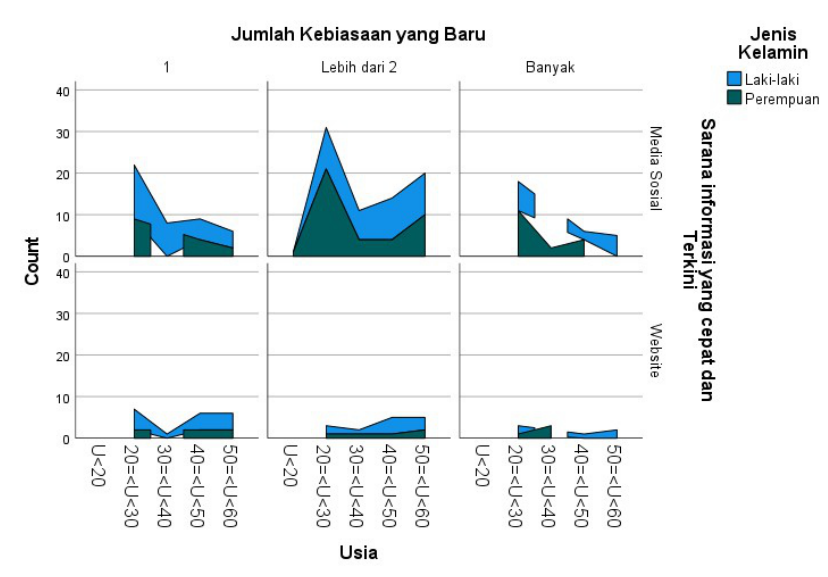

Gambar 3. Grafik jumlah kebiasaan baru dan jenis aplikasi dalam penggunaan gadget

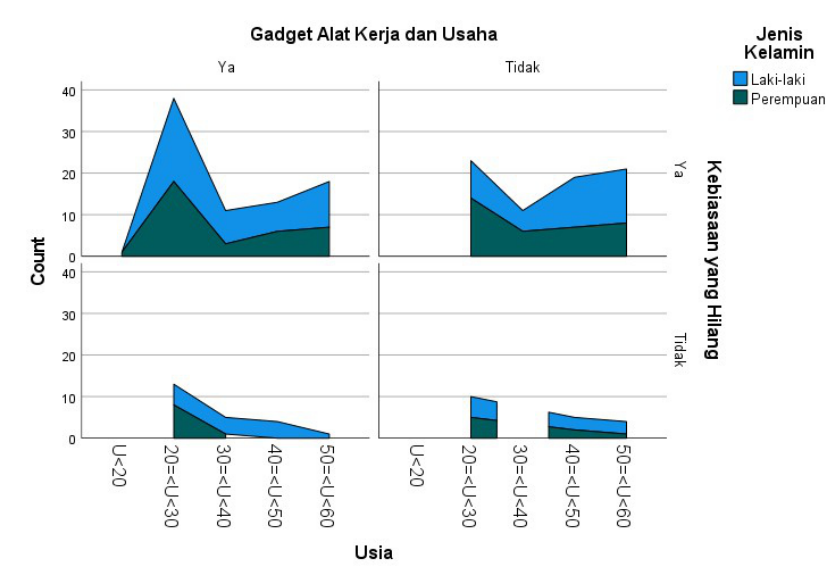

Gambar 4. Grafik antara fungsi gadget dan kebiasaan lama yang hilang 
Gambar 2). Ada juga yang tidak merasa kehilangan kebiasaan lama dan tidak memperoleh kebiasaan baru sebanyak 16 responden laki-laki $(8,1 \%)$ pada rentang usia 20-50 tahun. Laki-laki mengalami perubahan kebiasaan lebih besar dibanding perempuan, tetapi perbedaannya tidak signifikan (koefisien korelasinya -0,39).

Perubahan kebiasaan paling tinggi terjadi pada rentang usia antara 20-30 tahun, dan sebagian besar di antaranya adalah yang memiliki perilaku sebagai pengguna media sosial (Gambar 3). Baik responden yang memiliki kebiasaan menggunakan gadget sebagai alat kerja dan usaha maupun yang tidak, sebagian besar di antaranya mengalami kehilangan kebiasaan lama (Gambar 4).

Dalam hal pemahaman terhadap Objek Pemajuan Kebudayaan (OPK), yang diukur adalah mengenai manuskrip, permainan tradisional, dan tradisi lisan. Sebanyak 70,1\% responden menyatakan tidak pernah memanfaatkan Manuskrip, dan 29,9\% menyatakan pernah. Jawaban responden atas pemanfaatan manuskrip tidak berhubungan secara signifikan baik dengan jenis kelamin maupun dengan kategori usia (lihat Tabel 2).

Tentang Permainan Tradisional, sebanyak 75,1\% menyatakan tidak pernah memainkannya, sedangkan 24,9\% pernah memainkannya. Hubungan antara pernah memainkan Permainan Tradisional dengan usia signifikan dengan koefisien korelasi 0,218 . Hal itu menunjukkan bahwa pernah tidaknya memainkan permainan tradisional bergantung pada usia. Sementara dengan jenis kelamin, pernah tidaknya memainkan permainan tradisional tidak berhubungan signifikan.

Permainan tradisional yang pernah dilakukan oleh responden akan tetapi saat ini sudah tidak lagi dimainkan, diperlihatkan pada Gambar 5.

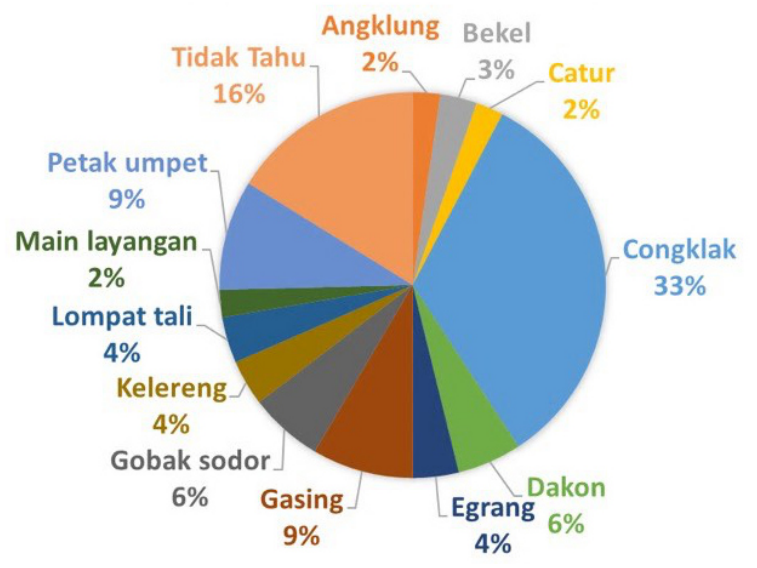

Gambar 5. Persentase responden yang pernah memainkan Permainan Tradisional tapi sekarang sudah tidak memainkannya lagi

Terhadap Permainan Tradisional yang terdapat dalam gadget yang bisa dimainkan dengan aplikasi game juga sebagian besar responden (82\%) menyatakan tidak tahu dan tidak pernah memainkannya, Sebagian kecil lainnya pernah memainkannya, seperti Congklak atau ular tangga (lihat Gambar 6).

Tingkat pemahaman responden terhadap OPK lainnya, yaitu tradisi lisan, sebanyak $73,6 \%$ menyatakan tidak mengetahui artinya, dan sebanyak 26,4\% menyatakan mengetahui, Pemahaman pada tradisi lisan ini berhubungan signifikan dengan usia, dengan koefisien korelasi sebesar -0,220 (lihat Tabel 2).

Kemudian responden diminta menyebutkan contoh dari tradisi lisan. Sebanyak 26,0\% jawabannya benar, 48,7\% jawabannya salah, dan $15,2 \%$ tidak menjawab. Jawaban

Tabel 2. Koefisien korelasi antar variabel

\begin{tabular}{|c|c|c|c|c|c|c|c|c|c|c|c|c|}
\hline & &  & $\frac{\pi}{n}$ & 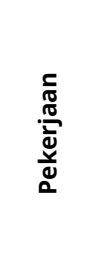 &  & 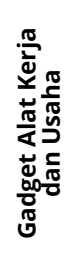 & 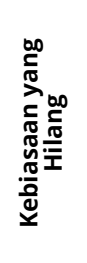 & 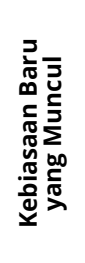 & 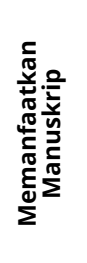 & 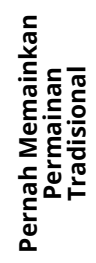 & 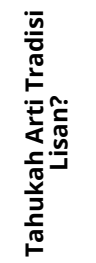 & 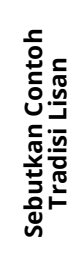 \\
\hline \multirow[t]{3}{*}{ Jenis Kelamin } & $\begin{array}{l}\text { Pearson } \\
\text { Correlation }\end{array}$ & 1 & $-.158 *$ & .072 & .043 & .039 & -.039 & $-.152 *$ & -.043 & -.056 & -.046 & -.043 \\
\hline & Sig. (2-tailed) & & .026 & .315 & .550 & .582 & .590 & .033 & .545 & .436 & .525 & .547 \\
\hline & $\mathrm{N}$ & 197 & 197 & 197 & 197 & 197 & 197 & 197 & 197 & 197 & 197 & 197 \\
\hline \multirow[t]{3}{*}{ Usia } & $\begin{array}{l}\text { Pearson } \\
\text { Correlation }\end{array}$ & $-.158 *$ & 1 & $-.206 * *$ & $-.181 *$ & $.172 *$ & -.133 & -.114 & -.001 & $.218^{* *}$ & $-.220 \star \star$ & $-.212^{\star \star}$ \\
\hline & Sig. (2-tailed) & .026 & & .004 & .011 & .016 & .062 & .112 & .988 & .002 & .002 & .003 \\
\hline & $\mathrm{N}$ & 197 & 197 & 197 & 197 & 197 & 197 & 197 & 197 & 197 & 197 & 197 \\
\hline
\end{tabular}

*. Correlation is significant at the 0.05 level (2-tailed).

**. Correlation is significant at the 0.01 level (2-tailed). 




Gambar 6. Kelompok responden berdasarkan permainan tradisional dalam gadget

responden tentang contoh tradisi lisan ini berhubungan signifikan dengan usia, dengan koefisien korelasi -0,212 (lihat Tabel 2).

\subsection{Analisis dan Pembahasan}

Sebagaimana dalam bagian pengolahan data pada huruf $b$ di atas, pemilihan jenis gadget tidak berhubungan dengan usia. Namun demikian, keragaman cara menggunakan gadget yang dibedakan berdasarkan fungsinya, yaitu sebagai (1) alat penyimpan data dan alat komunikasi; (2) alat kerja dan usaha; (3) sumber informasi yang cepat dan terkini; dan (4) sumber informasi yang lengkap, memiliki hubungan yang signifikan dengan usia. Sebanyak $43,2 \%$ responden menyimpan dan mengkomunikasikan lebih dari 75\% dokumen melalui gadget.

Dalam masa pandemi Covid-19 seperti sekarang ini, yang mengharuskan adanya WFH, gadget menjadi andalan utama dalam beraktivitas. Sebagaimana dikemukakan oleh Mungkasa (2020), orang bekerja dengan Home-Based Telecommuting itu memanfaatkan gadget sebagai sarana kerja, sarana usaha, menerima, mengolah, dan mengirimkan informasi.
Bila jenis penggunaannya dibedakan berdasarkan usia dan peralatan digital (gadget) yang digunakan, serta jenis sarana mencari informasi yang cepat dan terkini, responden yang usianya antara 20-30 tahun tampak dominan (lihat Gambar 7). Mereka, anak muda ini, sebagian besar adalah pengguna handphone dan media sosial.

Hal ini sejalan dengan yang dikemukakan oleh Sari (2019, hal. 34) yang menyatakan bahwa mereka yang saat ini berusia antara 20-40 tahun (Generasi Milenial) sangat kuat literasi medianya, apalagi mereka yang tergolong Generasi Z, yaitu yang lahir antara tahun 2000-2010. Mereka sangat digital (digital savvy). Sejumlah pihak banyak yang sudah memanfaatkan kaum yang menguasai keahlian digital savvy ini untuk pengembangan komunikasi massa, salah satunya adalah Humas Polda D.I Jogjakarta (Asri, 2018, hal. 111).

Namun demikian, dari hasil riset Iswanti dkk. (2020, hal. 820), penggunaan gadget yang terlalu intensif dapat juga menimbulkan efek negatif bagi penggunanya, yaitu penggunanya menjadi kurang peka, interaksi sosialnya rendah, dan cenderung menjadi byperpersonal. Semakin lama penggunaan gadget, semakin besar pengaruhnya (Putri dkk., 2020, hal. 85). Untuk mengatasi hal tersebut bisa menggunakan reality therapy. Maria dan Raharjo (2020, hal. 146) membuktikan melalui penelitiannya bahwa reality therapy dapat digunakan secara efektif untuk mendiagnosis dan mengurangi kebiasaan negatif, serta mencarikan alternatif kebiasaan yang lebih positif.

Dari hasil penelitian ini diperoleh informasi bahwa 78,7\% responden merasa kehilangan sejumlah kebiasaan lama setelah terbiasa menggunakan gadget, dan 91,9\% responden merasa memperoleh kebiasaan baru. Jenis-jenis kebiasaan lama yang hilang dan kebiasaan baru yang muncul yang dikemukakan oleh responden diperlihatkan dalam Gambar 8 persentase respondennya. Responden menuliskan jenis kebiasaan.

Sebanyak $56,4 \%$ responden mengaku kehilangan kebiasaan lama lebih dari dua jenis kebiasaan, dan 67,0\% responden mengaku mendapat kebiasaan baru lebih dari dua jenis.
Gambar 7. Jumlah responden yang menyatakan sarana informasi cepat/terkini terhadap jenis perangkat digital (gadget) yang digunakan dibedakan berdasarkan usia

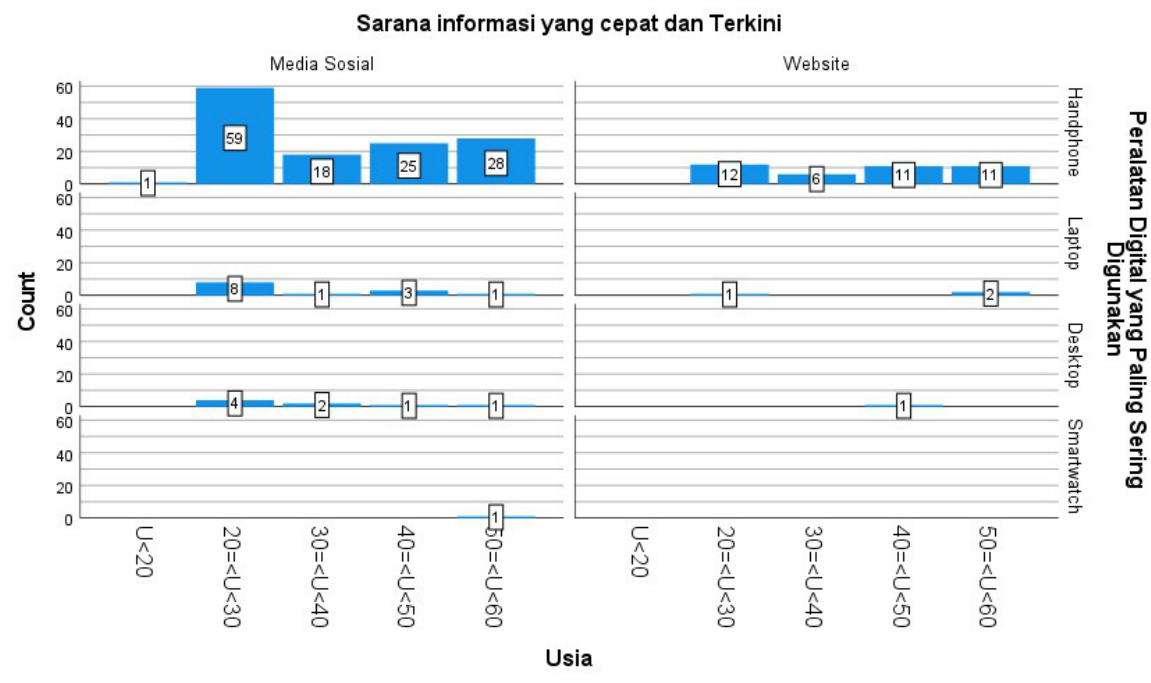




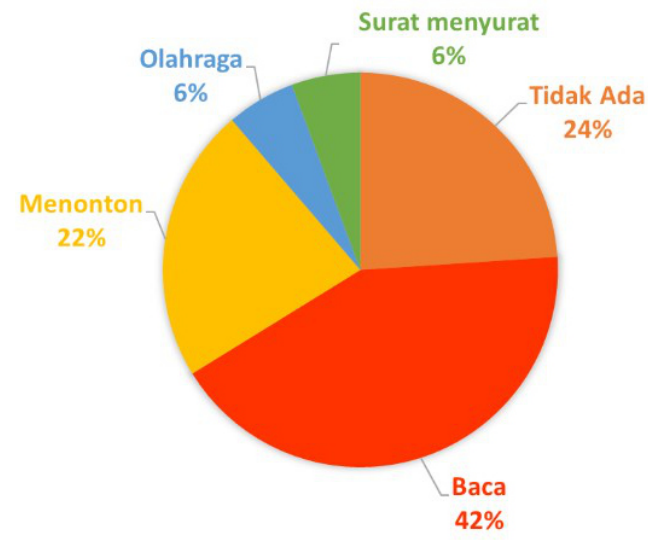

a. Kebiasaan lama yang hilang tanpa gadget

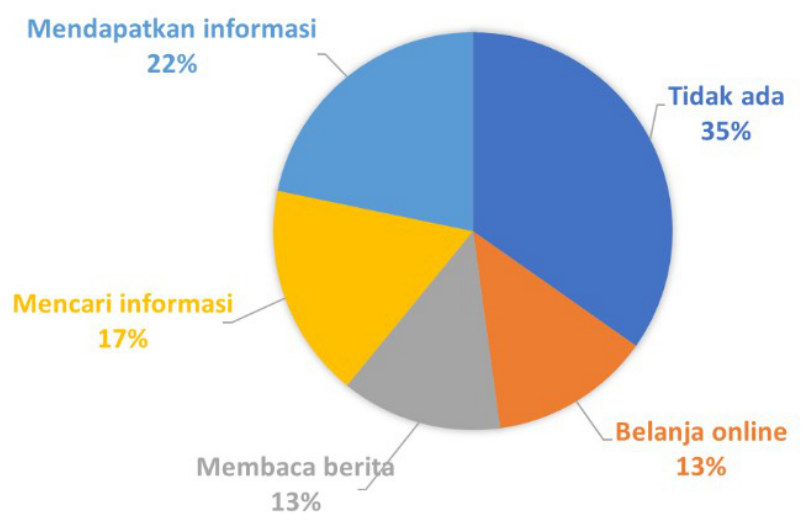

b. Kebiasaan baru yang muncul dengan gadget

Gambar 8. Persentase responden yang kehilangan kebiasaan lama dan memperoleh kebiasaan baru terkait penggunaan gadget (Responden menuliskan jenis kebiasaan)

Namun demikian, tidak ada responden yang merasa kehilangan kebiasaan lama tapi tidak memperoleh kebiasaan baru (lihat Gambar 8b).

Perubahan kebiasaan tersebut tidak berhubungan secara signifikan dengan usia. Dengan kata lain, perubahan kebiasaan bisa terjadi pada usia berapa pun yang menggunakan gadget secara intensif. Hal itu sejalan dengan hasil penelitian Haratanti dkk. (2019) dalam penggunaan gadget pada anak pra-sekolah dan Frahasini dkk. (2018, hal. 167) pada anak-anak sekolah yang sama-sama menyatakan gadget berpengaruh pada anak, dan Setiawan (2018, hal. 72) yang menemukan adanya pergeseran budaya akibat perkembangan teknologi informasi pada usia dewasa.

Dengan merebaknya penggunaan gadget itu dan bergesernya kebiasaan berperilaku, pada penelitian ini dicoba ditelaah juga mengenai pemahaman responden tentang OPK yang di antaranya manuskrip, permainan tradisional, dan tradisi lisan. Untuk variabel permainan tradisional dan tradisi lisan itu berhubungan signifikan dengan usia pengguna, tetapi dengan jenis kelamin tidak. Artinya, usia responden yang berbeda memiliki pemahaman terhadap permainan tradisional



dan tradisi lisan itu berbeda, tidak bergantung pada jenis kelamin.

Bila responden dipisahkan berdasarkan usia, maka responden yang usianya antara 20-30 tahun sebagian besar kurang memahami tradisi lisan dan permainan tradisional (lihat Gambar 9). Begitu ditanyakan pernah tidaknya memainkan permainan tradisional, sebagian besar responden yang berusia 20-30 tahun menyatakan tidak pernah.

Hal yang menarik dari jawaban responden adalah saat diminta menyebutkan contoh tradisi lisan. Mereka yang mengaku mengetahui tradisi lisan sebagian besar menjawab salah dalam memberikan contoh dari tradisi lisan (lihat Gambar 10 pada grafik bagian tengah atas). Di samping itu responden yang mengaku tidak mengetahui tradisi lisan, sebagian besar responden usia 20-30 tahun tidak memberikan jawaban (lihat Gambar 10 pada grafik bagian kanan bawah).

Temuan ini menunjukkan bahwa sebagian besar responden usia muda belum mengenal cukup baik Objek Pemajuan Kebudayaan (OPK) yang merupakan kebudayaan turun temurun dari sejak zaman dahulu seperti tradisi lisan atau permainan tradisional tersebut. Hal itu sejalan dengan

Gambar 9. Jumlah responden terkait pemahaman pada Tradisi Lisan dan Permainan Tradisional berdasarkan usia

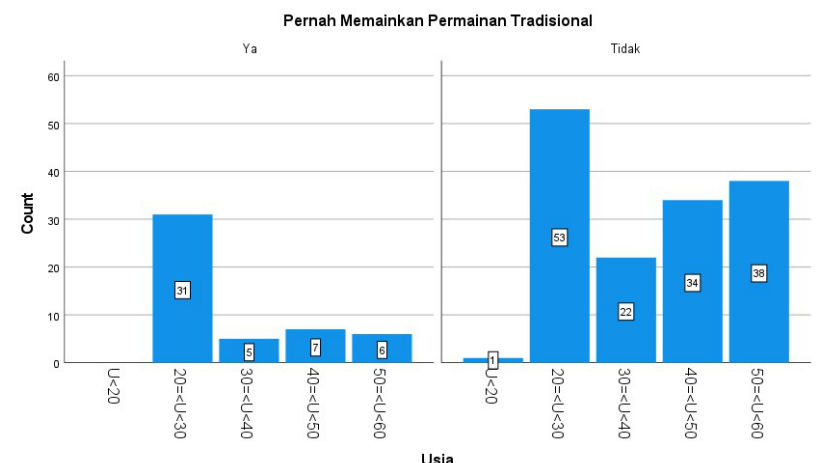

Usia

Gambar 


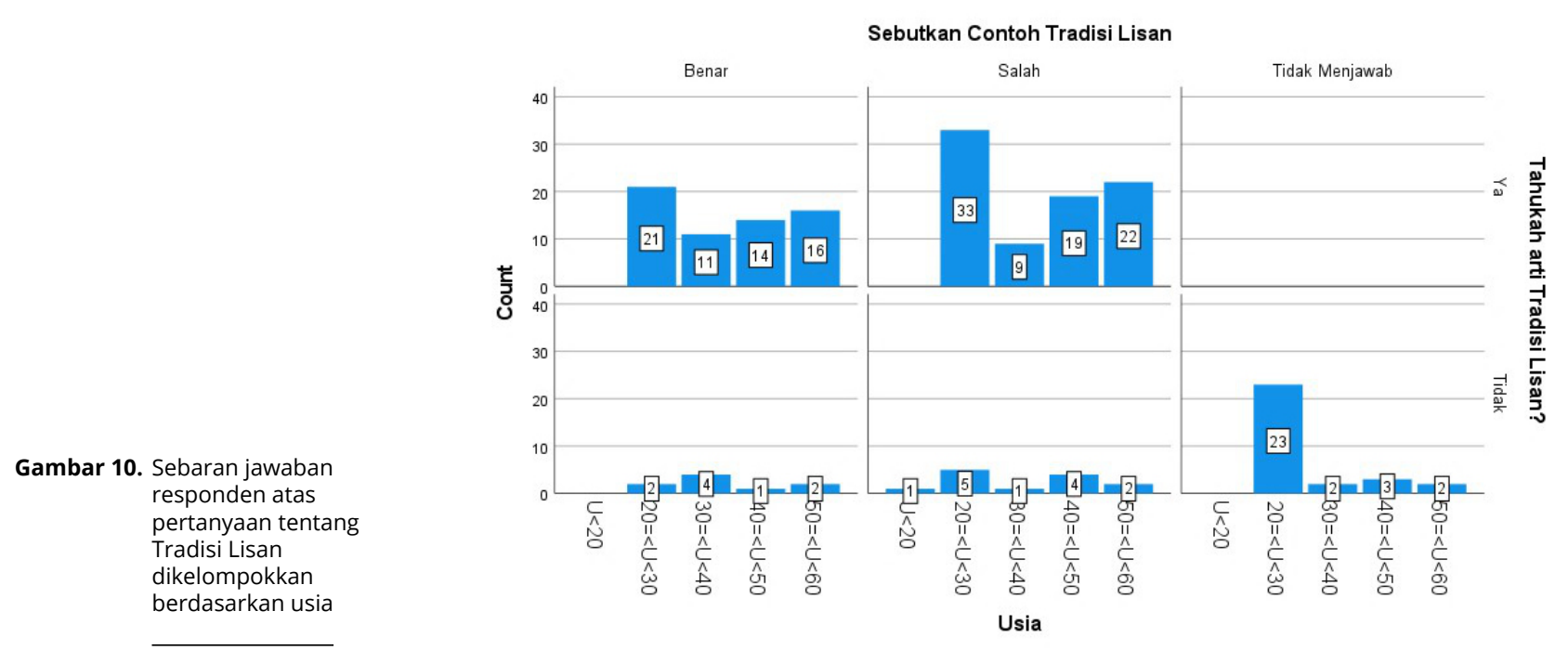

pendapat Witular dkk. (2019, hal. 1) yang menyatakan bahwa kebudayaan semakin ditinggalkan akibat majunya teknologi digital. Bahkan pada usia dini pun gejala tersebut mulai tampak akibatnya. Sebagai contoh dari hasil penelitian Munisa (2020, hal. 113) yang melakukan riset tentang penggunaan gadget pada usia anak-anak prasekolah, diketahui bahwa anakanak malas beraktivitas, dan mereka mulai melupakan kesenangan bermain bersama teman-temannya. Itu berarti mereka juga tidak bermain dengan permainan tradisional.

Dari hasil pengolahan data yang ditampilkan dalam bentuk grafik (Gambar 11), terlihat bahwa responden yang menggunakan Media Sosial, menggunakan gadget sebagai alat kerja dan alat usaha, sebagian besar salah dalam menjawab tradisi lisan dan menyatakan tidak pernah memainkan permainan tradisional (lihat lingkaran merah putus-putus pada Gambar 11). Cara membacanya, data pada tanda lingkaran itu responden yang menyebutkan contoh tradisi lisan salah itu juga tidak pernah memainkan permainan tradisional adalah mereka yang menggunakan gadget sebagai alat kerja dan usaha, menggunakan media sosial, dan yang menganggap bahwa gadget merupakan sarana informasi yang cepat dan terkini.

Fajrin (2015, hal. 27) yang melakukan penelitian pada anak yang sering menggunakan gadget menemukan bahwa mereka jarang melakukan permainan tradisional karena gadget cukup menyita waktu mereka, tetapi masih untung mereka terbantu dengan adanya permainan tradisional di sekolah bersama teman-temannya. Di pihak lain, penggunaan gadget bermanfaat untuk membantu kelancaran belajar dalam perkuliahan, seperti yang diuraikan oleh Octavianus dan Weismann (2021, hal. 71) bahwa sebanyak 81\% mahasiswa meningkat indeks prestasinya setelah menggunakan gadget sebagai alat bantu pembelajaran.

Di sisi lain, rendahnya pemahaman dan jarangnya dilakukan permainan tradisional itu bisa ditingkatkan dengan dihidupkannya kembali kelompok-kelompok hobi pada anakanak berdasarkan minat terhadap jenis permainan tertentu. Hasil penelitian Anggita dkk. (2018, hal. 57) mengenai eksistensi permainan tradisional pada anak-anak sekolah di Semarang menunjukkan bahwa permainan tradisional masih
Gambar 11. Responden dikelompokkan berdasarkan cara menggunakan gadget, Tradisi Lisan, Permainan Tradisional, dan usia

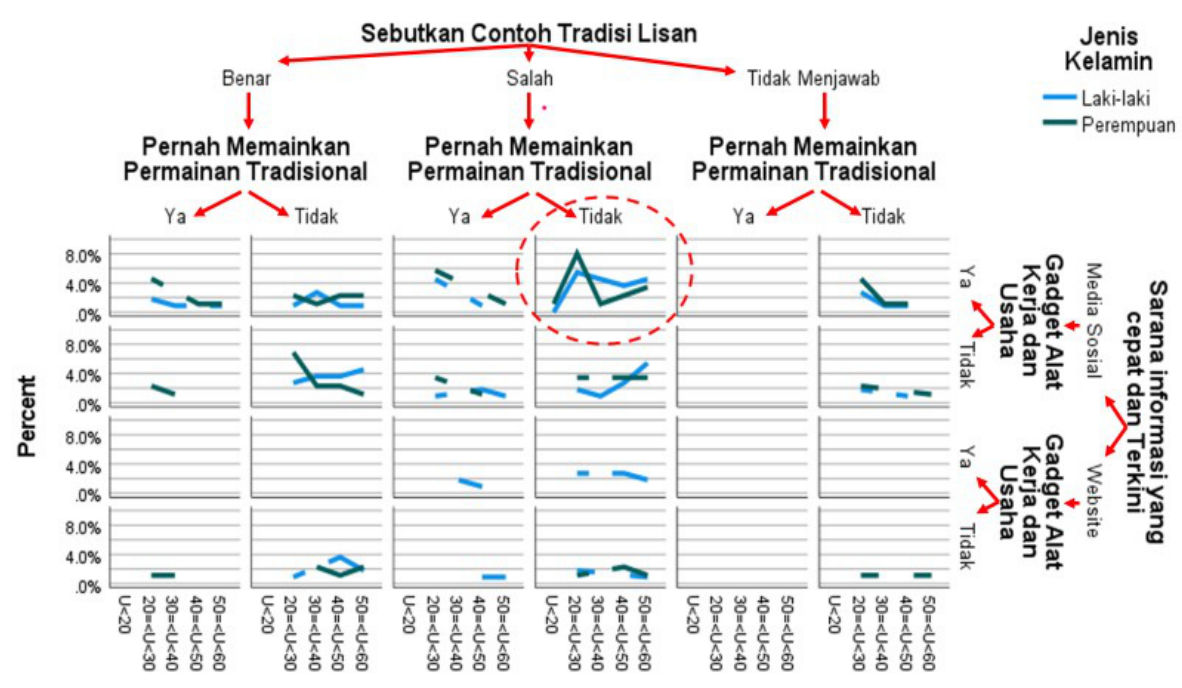


Gambar 12. Jumlah responden tentang pemahaman terhadap Manuskrip berdasarkan Usia dan Jenis Kelamin

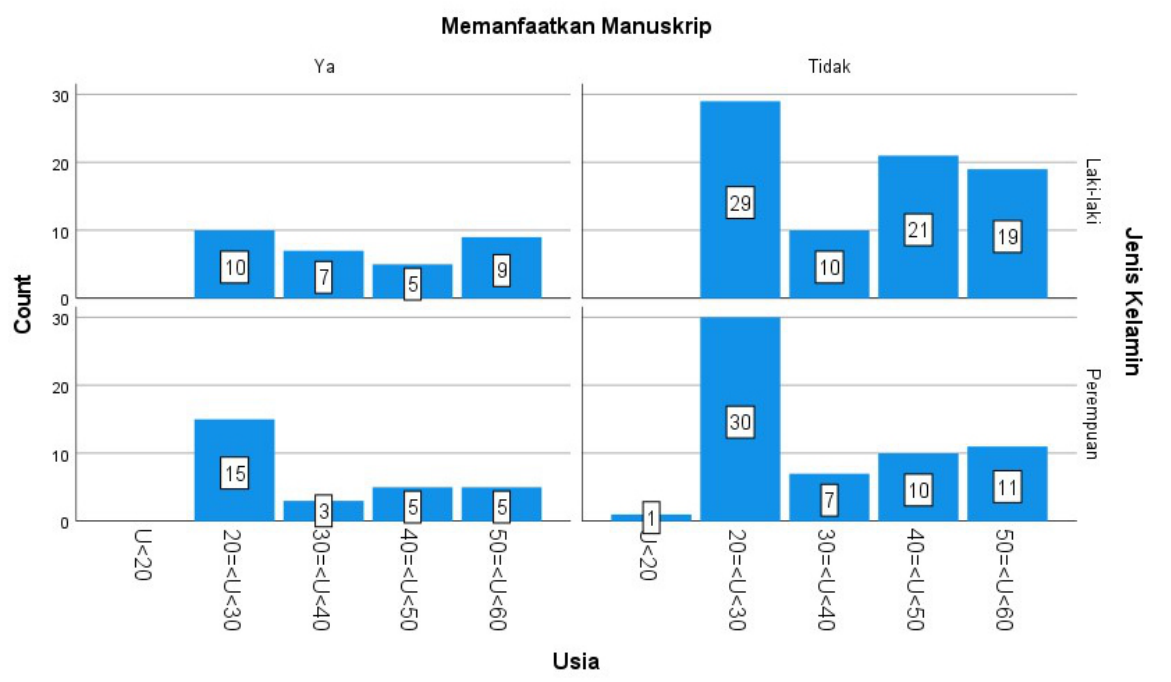

marak dilakukan sebab di sekolah-sekolah masih diadakan kegiatan khusus tentang kegiatan permainan tradisional yang secara sengaja dibina oleh guru olahraga. Cara lain untuk meningkatkannya bisa juga dengan mengubah pola asuh bagi anak-anak (Farida dkk., 2021). Bagi remaja dan orang dewasa bisa diarahkan untuk menjadi pengembang aplikasi untuk game-game bertema permainan tradisional.

Berikutnya, terkait manuskrip, data menunjukkan bahwa pemahaman responden tentang manuskrip rendah, dan tidak berhubungan secara signifikan dengan usia, begitu juga dengan jenis kelamin. Artinya pemahaman manuskrip itu tidak bergantung pada usia dan jenis kelamin. Dari data yang ditunjukkan pada Gambar 12 terlihat bahwa baik laki-laki maupun perempuan sebagian besar belum pernah memanfaatkan manuskrip (70\%) dan sebanyak 30\% di antara mereka berusia pada rentang 20-30 tahun.

Walaupun hubungannya tidak signifikan, tetapi responden pada rentang usia 20-30 tahun lebih banyak yang tidak mengenal manuskrip dibanding responden pada usia lainnya, baik laki-laki maupun perempuan (lihat Gambar 12).

Responden yang kurang memahami Manuskrip kurang memahami juga tradisi lisan dan permainan tradisional. Hubungan antara manuskrip dengan tradisi lisan dan permainan tradisional signifikan dengan koefisien korelasi masing-masing sebesar 0,19 dan 0,239 (lihat Tabel 3).

Karena hubungannya signifikan, maka dapat dikatakan bahwa responden yang tidak pernah memanfaatkan

Tabel 3. Korelasi antar OPK dan jenis kelamin

\begin{tabular}{|c|c|c|c|c|c|}
\hline & & Jenis Kelamin & $\begin{array}{l}\text { Pernah } \\
\text { Memainkan } \\
\text { Permainan } \\
\text { Tradisional }\end{array}$ & $\begin{array}{l}\text { Tahukah arti } \\
\text { Tradisi Lisan? }\end{array}$ & $\begin{array}{c}\text { Sebutkan } \\
\text { Contoh Tradisi } \\
\text { Lisan }\end{array}$ \\
\hline \multirow[t]{3}{*}{ Jenis Kelamin } & Pearson Correlation & 1 & -.056 & -.046 & -.043 \\
\hline & Sig. (2-tailed) & & .436 & .525 & .547 \\
\hline & $\mathrm{N}$ & 197 & 197 & 197 & 197 \\
\hline \multirow{3}{*}{$\begin{array}{l}\text { Pernah Memainkan Permainan } \\
\text { Tradisional }\end{array}$} & Pearson Correlation & -.056 & 1 & .025 & -.038 \\
\hline & Sig. (2-tailed) & .436 & & .729 & .599 \\
\hline & $\mathrm{N}$ & 197 & 197 & 197 & 197 \\
\hline \multirow[t]{3}{*}{ Tahukah arti Tradisi Lisan? } & Pearson Correlation & -.046 & .025 & 1 & $.535^{\star *}$ \\
\hline & Sig. (2-tailed) & .525 & .729 & & .000 \\
\hline & $\mathrm{N}$ & 197 & 197 & 197 & 197 \\
\hline \multirow[t]{3}{*}{ Sebutkan Contoh Tradisi Lisan } & Pearson Correlation & -.043 & -.038 & $.535^{\star \star}$ & 1 \\
\hline & Sig. (2-tailed) & .547 & .599 & .000 & \\
\hline & $\mathrm{N}$ & 197 & 197 & 197 & 197 \\
\hline
\end{tabular}

**. Correlation is significant at the 0.01 level (2-tailed) 




Manuskrip sebagian besar tidak pernah juga memainkan permainan tradisional dan mayoritas berusia antara 20-30 tahun. Hasil pengolahan data dalam bentuk grafik menunjukkan kecenderungan bahwa hampir semua yang menyatakan tidak pernah memanfaatkan manuskrip itu mereka juga tidak pernah memainkan permainan tradisional (lihat Gambar 13 pada bagian kanan bawah).

Namun demikian, terkait manuskrip, dari data yang ada, tidak ada bukti bahwa kurangnya pemahaman manuskrip pada segala usia responden tersebut itu disebabkan oleh penggunaan gadget. Patut diduga penyebabnya berasal dari hal yang lain.

Manuskrip adalah tulisan tangan pada lontar, rotan, kertas, daun, atau kulit kayu. Itu merupakan warisan nenek moyang, barang kuno dan sangat jarang, serta biasanya tersimpan di tempat khusus. Nopriani dan Rodin (2020, hal. 23) dalam artikel jurnalnya menyatakan bahwa manuskrip sangat rentan dari kerusakan fisik, saat ini masih banyak yang belum dikonservasi, sehingga fokus penanganannya sampai saat ini adalah mengenai proses penyelamatan.

Karena masih fokus pada penyelamatan, maka manuskrip belum banyak dimanfaatkan dan dieksploitasi. Akibatnya manuskrip masih jarang diketahui dan dikenal khalayak, seperti halnya ditunjukkan dalam data penelitian ini.

Mengingat manuskrip mengandung nilai-nilai luhur di dalamnya dan sangat berguna bagi generasi penerus, maka pengenalan, publikasi, dan pemanfaatan Manuskrip menjadi penting dilakukan. Caranya bisa dengan menggunakan teknologi digital yang bisa diakses melalui gadget. Arifianto (2019, hal. 129) menyarankan bahwa bidang Desain Komunikasi Visual (DKV) dapat dimanfaatkan sebagai alat produksi atau media publikasi dan promosi. DKV selain dapat difungsikan sebagai pemberi informasi, juga dapat digunakan sebagai alat untuk persuasi.

Sesungguhnya Objek Pemajuan Kebudayaan (OPK) secara keseluruhan itu berdasarkan Undang-undang Nomor 5 Tahun
2017 Tentang Pemajuan Kebudayaan ada sepuluh, yaitu (1) Tradisi Lisan; (2) Manuskrip; (3) Adat Istiadat; (4) Permainan Rakyat; (5) Olahraga Tradisional; (6) Pengetahuan Tradisional; (7) Teknologi Tradisional; (8) Seni; (9) Bahasa; dan (10) Ritus. Oleh karena itu tidak tertutup kemungkinan tujuh OPK lainnya juga masih banyak yang belum dikenal atau sudah jarang dimanfaatkan oleh masyarakat saat ini seperti halnya tiga hal yang diteliti tersebut. Sebab kesepuluh OPK itu sesungguhnya sama-sama objek lama dan relatif diajarkan turun-temurun secara tradisional.

Rukmini (2021) mengemukakan bahwa perubahan budaya banyak dipengaruhi oleh modernisasi dan teknologi. Salah satu bidang teknologi yang dimaksud adalah teknologi informasi yang dalam hal ini bisa berupa gadget. Gadget ini akan memiliki dampak negatif bila kita lemah, seperti rendahnya pendidikan atau lemahnya integritas. Hal itu juga akan menimbulkan lunturnya budaya daerah dan ditinggalkannya norma-norma kearifan lokal (Witular dkk., 2019). Dalam hal ini, bisa dikatakan bahwa yang keliru itu adalah cara memfungsikan gadget bukan pada gadgetnya itu sendiri.

Gadget yang memiliki multifungsi sesungguhnya dapat dimanfaatkan untuk banyak hal positif, termasuk memajukan kebudayaan, mengeksplorasi dan mengeksploitasi kekayaan budaya yang selama ini belum termanfaatkan. Sari (2019) menyarankan, untuk pemajuan kebudayaan, termasuk mengembangkan OPK, bisa menggunakan literasi media. Sejauh ini literasi media belum dimanfaatkan untuk OPK.

Hal itu perlu untuk lebih mengarahkan konsentrasi pengguna gadget pada hal-hal yang lebih positif. Apalagi saat ini jumlah usia produktif sangat dominan, disebut sebagai Bonus Demografi. Kaum milenial yang berusia 20-35 tahun saja jumlahnya tidak kurang dari 63 juta (Prasasti \& Prakoso, 2020, hal. 16).

Jumlah tersebut akan berpengaruh signifikan terhadap perubahan budaya. Keahlian digital savvy yang mereka miliki dapat diarahkan untuk membangun aplikasi atau produkproduk media terkait dengan sepuluh OPK tersebut, misalnya 
Tabel 4. Dokumen disimpan dan dikomunikasikan dalam gadget

\begin{tabular}{cccccr}
\hline & Frequency & Percent & \multicolumn{1}{c}{$\begin{array}{c}\text { Valid } \\
\text { Percent }\end{array}$} & $\begin{array}{c}\text { Cumulative } \\
\text { Percent }\end{array}$ \\
\hline Valid & $0 \%$ & 5 & 2.5 & 2.5 & 2.5 \\
\hline $25 \%$ & 48 & 24.4 & 24.4 & 26.9 \\
\hline $50 \%$ & 59 & 29.9 & 29.9 & 56.9 \\
\hline $75 \%$ & 65 & 33.0 & 33.0 & 89.8 \\
\hline $100 \%$ & 20 & 10.2 & 10.2 & 100.0 \\
\hline Total & 197 & $\mathbf{1 0 0 . 0}$ & $\mathbf{1 0 0 . 0}$ & \\
\hline
\end{tabular}

pengembangan aplikasi bagi olahraga tradisional, pembuatan game permainan rakyat, atau pemanfaatan dan aplikasi pengetahuan tradisional.

Potensi penggunaan gadget ke arah yang lebih positif, khususnya pada kalangan responden yang berasal dari PNS, BUMN, karyawan swasta, atau pemilik usaha, tampaknya sudah ada. Data menunjukkan bahwa mereka memfungsikan gadget sebagai alat bantu utama pekerjaan.

Lebih dari $73,1 \%$ responden sudah terbiasa menyimpan dan mengkomunikasikan lebih dari 50\% dokumen dalam gadget yang diperlukan untuk mendukung pekerjaan (lihat Tabel 4). Pada kelompok responden ini gadget mampu membantu mengubah budaya kerja yang tadinya offline menjadi online, baik antar individu, individu dengan instansi, dan instansi dengan instansi, atau individu dan instansi dengan masyarakat.

Pengoptimalan fungsi gadget pada kelompok mahasiswa dan remaja dapat melalui kreasi pada pengembangan programprogram aplikasi baik untuk perubahan budaya dalam dunia hiburan maupun perubahan budaya dalam bidang bisnis, seperti halnya aplikasi startup. Gadget juga bisa untuk mengubah budaya belajar agar pembelajaran bisa lebih efektif dan efisien (Octavianus \& Weismann, 2021).

Pada kalangan anak-anak, pengoptimalan fungsi gadget agar perubahan budaya dalam penggunaan gadget bisa lebih optimal bagi perkembangan fisik maupun psikis anak-anak bisa dilakukan melalui perubahan pola asuh anak. Farida dkk. (2021) memberikan penekanan pada pentingnya orang tua dan guru-guru mendampingi anak-anak dalam penggunaan gadget sambal memberikan pemahaman pada anak-anak bahwa gadget sangat bermanfaat dalam membantu menyelesaikan beberapa permasalahan.

\section{Kesimpulan}

Berdasarkan hasil pengolahan data yang telah dilakukan dapat disimpulkan hal-hal sebagai berikut. Penggunaan gadget dan perubahan budaya memiliki hubungan yang signifikan dengan usia penggunanya. Tetapi jenis gadget yang digunakan tidak berhubungan signifikan dengan usia dan jenis kelamin.

Keragaman cara menggunakan gadget seperti sebagai alat penyimpan data, alat komunikasi, alat kerja dan alat usaha berbeda signifikan terhadap usia. Sarana informasi yang mudah, cepat dan terkini sebagian besar diakses melalui media sosial, dan hubungannya signifikan dengan usia pengguna.

Kebiasaan lama yang hilang dan kebiasaan baru yang muncul setelah menggunakan gadget tidak berhubungan signifikan dengan usia serta jenis kelamin. Objek Pemajuan Kebudayaan seperti tradisi lisan, atau permainan tradisional banyak tidak dikenal responden. Tingkat pemahamannya signifikan dengan usia, tetapi pemahaman terhadap Manuskrip tidak berhubungan signifikan dengan usia, yang berarti bahwa pemahamannya rendah untuk segala usia.

Namun demikian, karena gadget memiliki multifungsi, maka penggunaannya bisa lebih diarahkan ke hal-hal yang lebih positif, di antaranya adalah melalui pemanfaatan Desain Komunikasi Visual untuk mengeksplorasi nilai-nilai luhur yang belum tergali, memproduksi bahan-bahan edukasi dan publikasi, serta proses literasi media, terutama bagi kalangan generasi milenial.

\section{Ucapan Terima Kasih}

Ucapan terima kasih kami sampaikan kepada Bapak/lbu/Saudara yang telah membantu menyebarkan dan bersedia mengisi survei kami. Ucapan terima kasih juga kami sampaikan kepada yang terhormat Bapak Nyoman Shuida selaku Deputi Bidang Koordinasi Revolusi Mental, Pemajuan Kebudayaan, dan Prestasi Olahraga, Kementerian Koordinator Bidang Pembangunan Manusia dan Kebudayaan yang telah memberikan arahan dalam penelitian ini. Penelitian ini bersifat pribadi, tidak mewakili dan/atau mengatasnamakan kebijakan institusi di mana peneliti bekerja.

\section{Referensi}

Adrian, K. (2019, September 1). Ini Ciri-Ciri Kecanduan Gadget dan Tips Menanggulanginya. Alodokter. https://www.alodokter.com/ini-ciri-cirikecanduan-gadget-dan-tips-menanggulanginya

Anggita, G. M., Mukarromah, S. B., \& Ali, M. A. (2018). Eksistensi Permainan Tradisional sebagai Warisan Budaya Bangsa. Journal of Sport Science and Education (JOSSAE), 3(2), 55-59. https://doi.org/10.26740/ jossae.v3n2.p55-59

Arifianto, P. F. (2019). Pendidikan Desain Komunikasi Visual dan Upaya Pemajuan Kebudayaan Indonesia. Prosiding Seminar Nasional Desain dan Arsitektur (SENADA), 2, 120-130. https://eprosiding.idbbali.ac.id/ index.php/senada/article/view/121

Asri, R. H. (2018). Strategi Komunikasi Humas Polda D. I. Yogyakarta Melalui Skill Digital Savvy di Era Disruptif. Expose - Jurnal IImu Komunikasi, 1(2), 95-113. https://doi.org/10.33021/exp.v1i2.432

Dalillah. (2019). Pengaruh Penggunaan Gadget terhadap Perilaku Sosial Siswa di SMA Darussalam Ciputat [Universitas Islam Negeri Syarif Hidayatullah] http://repository.uinjkt.ac.id/dspace/handle/ 123456789/43397

Fajrin, O. R. (2015). Hubungan Tingkat Penggunaan Teknologi Mobile Gadget dan Eksistensi Permainan Tradisional pada Anak Sekolah 
Dasar. Jurnal Idea Societa, 2(6), 1-33. http:// jmsos.studentjournal.ub.ac.id/index.php/jmsos/article/view/107

Farida, A., Salsabila, U. H., Hayati, L. L. N., Ramadhani, J., \& Saputri, Y. (2021). Optimalisasi Gadget dan Implikasinya terhadap Pola Asuh Anak. Jurnal Inovasi Penelitian, 1(8), 1701-1710. https://doi.org/ 10.47492/jip.v1i8.316

Fitriana, Ahmad, A., \& Fitria. (2020). Pengaruh Penggunaan Gadget terhadap Perilaku Remaja dalam Keluarga. Psikoislamedia Jurnal Psikologi, 5(2), 182-194. https://doi.org/10.22373/ psikoislamedia.v5i2.7898

Frahasini, Astuti, T. M. P., \& Atmaja, H. T. (2018). The Impact of The Use of Gadgets in School of School Age Towards Children's Social Behavior in Semata Village. Journal of Educational Social Studies, 7(2), 161-168. https://doi.org/10.15294/jess.v7i2.26842

Haratanti, I. P., Noviati, R., \& Hukmi. (2019). The Influence of Gadget Intensity Use on Pro-Social Behaviour of Early Childhood. Proceeding of the SS9 \& 3rd URICES, 361-366. https://ices.prosiding.unri.ac.id/ index.php/ICES/article/view/7914

Hendrawati, T. (2018). Digitalisasi Manuskrip Nusantara sebagai Pelestari Intelektual Leluhur Bangsa. Media Pustakawan, 25(4), 24-32. https:// doi.org/10.37014/medpus.v25i4.196

Hermawan, A. (2021). Hubungan Penggunaan Gadget dengan Kemampuan Interaksi Sosial pada Siswa di Sekolah Dasar. Mahesa: Malahayati Health Student Journal, 1(1), 53-62. https://doi.org/10.33024/ mahesa.v1i1.3320

Iswanti, D. I., Lestari, S. P., \& Hani, U. (2020). Penggunaan Gadget terhadap Perilaku Sosial Remaja. Jurnal Keperawatan, 12(4), 815-822. https:// doi.org/10.32583/keperawatan.v12i4.1000

Maria, G. A. R., \& Raharjo, S. T. (2020). Adaptasi Kelompok Usia Produktif Saat Pandemi Covid-19 Menggunakan Metode Reality Therapy. Jurnal Kolaborasi Resolusi Konflik, 2(2), 142-149. https://doi.org/10.24198/ jkrk.v2i2.29124

Muhaemin, N. M. (2021). Bonus Demografi Jawa Barat dan Perencanaan Pembangunan Daerah: Sudah Siapkah Jawa Barat? Jurnal Academia Praja, 4(1), 201-222. https://doi.org/10.36859/jap.v4i1.269

Munawar, \& Amri, A. (2018). Pengaruh Gadget terhadap Interaksi dan Perubahan Perilaku Anak Usia Dini di Gampong Rumpet Kecamatan Krueng Barona Jaya Kabupaten Aceh Besar. Jurnal Ilmiah Mahasiswa FISIP Unsyiah, 3(3). http://www.jim.unsyiah.ac.id/FISIP/article/view/ 8255

Mungkasa, O. (2020). Bekerja dari Rumah (Working from Home/WFH): Menuju Tatanan Baru Era Pandemi COVID 19. Jurnal Perencanaan Pembangunan: The Indonesian Journal of Development Planning 4(2), 126-150. https://doi.org/10.36574/jpp.v4i2.119

Munisa. (2020). Pengaruh Penggunaan Gadget terhadap Interaksi Sosial Anak Usia Dini di TK Panca Budi Medan. Jurnal IImiah Abdi IImu, 13(1), 102-114. http://jurnal.pancabudi.ac.id/index.php/abdiilmu/ article/view/896
Nopriani, \& Rodin, R. (2020). Konservasi Naskah Manuskrip sebagai Upaya Menjaga Warisan Budaya Bangsa di Era Industri 4.0. Jupiter, XVII(1), 20-29. https://journal.unhas.ac.id/index.php/jupiter/article/view/11311

Octavianus, \& Weismann, I. T. J. (2021). Pengaruh Penggunaan Handphone terhadap Prestasi Belajar Mahasiswa Sekolah Tinggi Filsafat Jaffray Makassar. Repository STT Jaffray, 3(1), 71-80. https:// skripsi.sttjaffray.ac.id/index.php/skripsi/article/view/109

Prasasti, S., \& Prakoso, E. T. (2020). Karakter dan Perilaku Milineal: Peluang atau Ancaman Bonus Demografi. Consilia: Jurnal IImian BK, 3(1), 10-22. https://doi.org/10.33369/consilia.v3i1.11981

Putri, E. O., Utami, A., \& Lestari, R. F. (2020). Hubungan Lama Penggunaan Gadget dengan Perilaku Sosial Anak Pra Sekolah. Jurnal Cakrawala Promkes, 2(2), 80-86. https://doi.org/10.12928/promkes.v2i2.1832

Rahmawati, I., Kristiana, D., \& M.Fadlillah. (2020). Hubungan Penggunaan Gadget terhadap Perkembangan Sosial Emosional Anak Usia 5-6 Tahun di Era 4.0. Jurnal Edupedia, 4(2), 143-149. https://doi.org/ 10.24269/ed.v4i2.543

Rais, N. S. R., Dien, M. M. J., \& Dien, A. Y. (2018). Kemajuan Teknologi Informasi Berdampak pada Generalisasi Unsur Sosial Budaya bagi Generasi Milenial. Jurnal Mozaik, 10(2), 61-71. https://ijc.ilearning.co/ index.php/mozaik/article/view/755

Rukmini, D. (2021, Maret 25). Apa Saja Faktor Penyebab Perubahan Sosial: Internal dan Eksternal (A. M. Idhom (ed.)). tirto.id. https://tirto.id/apasaja-faktor-penyebab-perubahan-sosial-internal-dan-eksternal-gbvj

Sari, S. (2019). Literasi Media pada Generasi Milenial di Era Digital. Jurnal Professional FIS UNIVED, 6(2), 30-42. https://doi.org/10.37676/ professional.v6i2.943

Setiawan, D. (2018). Dampak Perkembangan Teknologi Informasi dan Komunikasi terhadap Budaya. SIMBOLIKA, 4(1), 62-72. https:// doi.org/10.31289/simbollika.v4i1.1474

Syawaludin, M. (2017). Teori Sosial Budaya dan Methodenstreit. NoerFikri.

Syifa, L., Setianingsih, E. S., \& Sulianto, J. (2019). Dampak Penggunaan Gadget terhadap Perkembangan Psikologi pada Anak Sekolah Dasar. Jurnal IImiah Sekolah Dasar, 3(4), 527-533. https://doi.org/10.23887/ jisd.v3i4.22310

Witular, D. P., Diah W., M., \& Dewi W., S. (2019, Juli 10). Pengaruh Teknologi Smartphone terhadap Kebudayaan. OSF Preprints. https://doi.org/ 10.31219/osf.io/rk5vy

Yanzi, H. (2018). Penguatan Tradisi Lisan Sebagai Upaya Eksistensi NilaiNilai Multikultur (hal. 1-14). http://repository.lppm.unila.ac.id/id/eprint/ 6637

Yoga, S. (2018). Perubahan Sosial Budaya Masyarakat Indonesia dan Perkembangan Teknologi Komunikasi. Jurnal Al-Bayan, 24(1), 29-46. https://doi.org/10.22373/albayan.v24i1.3175

Zulkarnain, I., Husaini, Baekhaki, K., \& Christian, F. Y. (2016). Relasi Antara Penggunaan Android dan Perubahan Sosial Perdesaan: Studi Perubahan Sosial di Kabupaten Bogor Jawa Barat. Jurnal Society, VI(II), 1-14. https://doi.org/10.33019/society.v4i2.25 